\title{
Collaborative study to evaluate the indigestible neutral detergent fiber and indigestible acid detergent fiber contents in feeds by in situ procedure
}

\author{
Estudo colaborativo para avaliação dos teores de fibra em \\ detergente neutro indigestível e fibra em detergente ácido \\ indigestível em alimentos por procedimento in situ
}

\author{
Marjorrie Augusto de Souza ${ }^{1}$; Edenio Detmann ${ }^{2 *}$; Gabriel Cipriano Rocha ${ }^{2}$; \\ Marcia de Oliveira Franco ${ }^{1}$; Erick Darlisson Batista ${ }^{1}$; \\ Sebastião de Campos Valadares Filho ${ }^{2}$; Telma Teresinha Berchielli ${ }^{3}$
}

\begin{abstract}
The objective of this collaborative study was to evaluate the indigestible neutral detergent fiber (iNDF) and indigestible acid detergent fiber (iADF) content in feeds in six laboratories from institutions linked to the National Institute of Science and Technology in Animal Science (INCT-CA). Six feeds were evaluated: signal grass hay, sugarcane, corn silage, soybean meal, corn and citrus pulp. Estimated levels of iNDF and iADF proved to be dependent on the laboratory in which the analysis was performed. It was found that differences between laboratories ranged from 2.40 percentage points for soybean meal to 8.05 percentage points for sugarcane for iNDF analysis and from 1.79 percentage points for corn to 10.06 percentage points for hay for $\mathrm{iADF}$ analysis. It was observed in the individual evaluation of each material that total random variation of the results between laboratories ranged from 88.75 to $96.77 \%$ and 88.75 to $98.40 \%$ for iNDF and iADF analysis, respectively. The iNDF and iADF levels are dependent on the interaction effect between the evaluated material and laboratory and have low reproducibility; this may be a consequence of the differences between the methods practiced by each laboratory, demonstrating lack of standardization of procedures used by the laboratories.

Key words: Analytical methods. Feed analysis. Indigestible fiber. Repeatability. Reproducibility.
\end{abstract}

\section{Resumo}

Objetivou-se conduzir estudo colaborativo para avaliação dos teores de fibra em detergente neutro indigestível (FDNi) e fibra em detergente ácido indigestível (FDAi) em alimentos em seis laboratórios de instituições integrantes do Instituto Nacional de Ciência e Tecnologia de Ciência Animal (INCTCA). Avaliaram-se seis alimentos: feno de capim-braquiária, cana-de-açúcar, silagem de milho, farelo de soja, milho grão e polpa cítrica. Os teores estimados de FDNi e FDAi se mostraram dependentes do laboratório em que a análise foi realizada. Verificou-se que as diferenças entre laboratórios variaram de 2,40 pontos percentuais para o farelo de soja a 8,05 pontos percentuais para a cana-de-açúcar para

\footnotetext{
${ }^{1}$ Discentes, Departamento de Zootecnia, Universidade Federal de Viçosa, UFV, Viçosa, MG, Brasil. E-mail: marjorrieas@yahoo. com.br; marciazoo1@yahoo.com.br; erickdarlisson@gmail.com

2 Profs., Departamento de Zootecnia, UFV, Viçosa, MG, Brasil. E-mail: detmann@ufv.br; gcrbrazil@gmail.com; scvfilho@ufv.br

${ }^{3}$ Prof $\mathrm{f}^{\mathrm{a}}$, Departamento de Zootecnia, Faculdade de Ciências Agrárias e Veterinárias, Universidade Estadual Paulista "Júlio de Mesquita Filho", UNESP, Jaboticabal, SP, Brasil. E-mail: ttberchi@fcav.unesp.br

* Author for correspondence
} 
a análise de FDNi e de 1,79 ponto percentual para o milho a 10,06 pontos percentuais para o feno para a análise de FDAi. Observou-se que na avaliação individual de cada material, a variação aleatória total dos resultados entre laboratórios correspondeu de 88,75 a $96,77 \%$ e de 88,75 a $98,40 \%$ para as análises de FDNi e FDAi, respectivamente. Os teores de FDNi e FDAi são dependentes do efeito de interação do material avaliado e do laboratório e apresentam baixa reprodutibilidade, possível reflexo das diferenças entre os métodos praticados por cada laboratório, demonstrando falta de padronização dos procedimentos adotados pelos laboratórios.

Palavras-chave: Análise de alimentos. Fibra indigestível. Métodos de análises. Repetibilidade. Reprodutibilidade.

\section{Introduction}

As a starting point to estimate the parameters of dietary digestibility, the apparent indigestibility, as its complement, must first be obtained. In this context, the fecal excretion is the basic parameter of feed or ration indigestibility, as it represents, at least apparently, the portion of the ingested feed not used during the passage through the gastrointestinal tract (DETMANN et al., 2004). However, due to the difficulty of carrying out total feces collection in large animals, such as cattle, indirect techniques with the use of markers are recommended.

Internal markers commonly used in assay with ruminants include the indigestible residue of the feeds, being commonly represented by physical fraction indigestible dry matter (iDM) or by chemical fractions indigestible neutral detergent fiber (iNDF) and indigestible acid detergent fiber (iADF) (DETMANN et al., 2004). However, due to analytical problems, the iDM has not been recommended as a marker (VALENTE et al., 2011a).

The estimates of fecal excretion are obtained through the cause-and-effect relationship between the feed/ration and the digestive events within the gastrointestinal tract (DETMANN et al., 2007). The basis for utilization of these relies on the fact that, as the feed transits through the gastrointestinal tract, the marker concentration increases progressively due to the withdrawal of the other components by digestion and absorption.

The verification of the characteristics of an ideal marker should focus on issues related to its recovery after being submitted to the events within the gastrointestinal tract, which, in theory, is an inherent characteristic of the marker itself (DETMANN et al., 2007). However, indirect influences of methods used for estimation of its concentration can cause apparent recovery bias (VALENTE et al., 2011a).

In addition, the importance of obtaining efficient estimates of digestibility coefficients resides in the fact that these estimates are a basic means of quantifying the energy value of feeds or rations, allowing the appropriate dietary balance that is able to meet the demands for maintenance and production of the animals (DETMANN et al., 2010).

Thus, it is necessary to evaluate the estimates of iNDF and iADF produced in different materials and different laboratories, seeking to identify the most appropriate methods and to standardize the procedures among feed analysis laboratories in the country.

The objective was to perform a collaborative study to evaluate the iNDF and iADF contents through in situ procedure in different feed samples in six different feed analysis laboratories of institutional members of the National Institute of Science and Technology in Animal Science (INCTCA).

\section{Material and Methods}

The evaluations were carried out in six feed analysis laboratories of institutional members of INCT-CA: Universidade Federal de Viçosa, Viçosa-MG; Veterinary School of the Universidade 
Federal de Minas Gerais, Belo Horizonte-MG; Universidade Federal de Lavras, Lavras-MG; Universidade Estadual de Santa Cruz, Ilhéus-BA; Universidade Estadual Paulista Júlio de Mesquita Filho, Jaboticabal-SP; and Universidade Federal de Mato Grosso, Cuiabá-MT; from May to June 2010.

Samples of six different feeds were evaluated: signal grass hay, fresh sugarcane, corn silage, soybean meal, corn grain and citrus pulp. Highmoisture samples were oven-dried $\left(60^{\circ} \mathrm{C}\right)$ and, together with the other samples, processed in a knife-mill (2-mm), packed in plastic bags and sent to laboratories without identification. Upon receipt of the samples, each laboratory was asked to conduct three replicates per sample.

In order to partially standardize the procedures, F57 bags (Ankom $\left.{ }^{\circledR}\right)$ were sent to be used in the evaluations, avoiding confounding related to the use of different textiles.

The results were requested on an as-is basis, because the evaluation of results with correction for the dry matter content of each sample between laboratories could encompass errors coming from two procedures (MERTENS, 2003).

A questionnaire was included with the samples, to elucidate the main procedures and the quantitative and qualitative analytical parameters adopted by each laboratory.

After obtaining the data, they were independently analyzed for iNDF and iADF according to the model:

$$
Y_{i j k}=\mu+L_{i}+M_{j}+L M_{i j}+\varepsilon_{(i j) k}
$$

where $\mathrm{Y}_{\mathrm{ijk}}$ is the NDFi or iADF content (\%) obtained in $\mathrm{k}$ replicate in the $\mathrm{i}$ laboratory and in the $\mathrm{j}$ material (feed); $\mu$ is the general constant; $\mathrm{L}_{\mathrm{i}}$ is the effect of $i$ laboratory (random); $M_{j}$ is the effect of $\mathrm{j}$ material or feed (fixed); $\mathrm{LM}_{\mathrm{ij}}$ is the interaction effect of $\mathrm{i}$ laboratory and $\mathrm{j}$ material (random); and $\mathrm{e}_{(\mathrm{ij}) \mathrm{k}}$ is the random error assumed to have normal distribution and homogeneous variance.
The expected mean squares for the analysis of variance were obtained by applying the method of moments (BARBIN, 1993) (Table 1). Outlier observations were defined when the deviation from the average value of the feed within a laboratory exceeded three times the residual standard deviation. The observations classified as outliers were eliminated from the data set.

Table 1. Expected mean squares for the model used in the general data analysis.

\begin{tabular}{cc}
\hline Variation source $^{1}$ & $\mathrm{E}(\mathrm{MS})^{2}$ \\
\hline $\mathrm{L}$ & $\sigma^{2}{ }_{\varepsilon}+\mathrm{k}_{1} \times \sigma_{\mathrm{L} \times \mathrm{M}}^{2}+\mathrm{k}_{2} \times \sigma_{\mathrm{L}}^{2}$ \\
$\mathrm{M}$ & $\sigma^{2}{ }_{\varepsilon}+\mathrm{k}_{1} \times \sigma^{2}{ }_{\mathrm{L} \times \mathrm{M}}+\mathrm{k}_{3} \times \phi_{\mathrm{M}}$ \\
$\mathrm{L} \times \mathrm{M}$ & $\sigma_{{ }_{\varepsilon}}^{2}+\mathrm{k}_{1} \times \sigma^{2}{ }_{\mathrm{L} \times \mathrm{M}}$ \\
Residue & $\sigma_{\varepsilon}^{2}$ \\
\hline
\end{tabular}

${ }^{1} \mathrm{~L}=$ laboratory; $\mathrm{M}=$ material; $\mathrm{L} \times \mathrm{M}=$ interaction laboratory $\times$ material. ${ }^{2} \sigma^{2}, \sigma_{\mathrm{LxM}}^{2}, \sigma^{2}=$ variances associated with the error effects (repeatability), interaction laboratory and material, and laboratory, respectively; $\phi_{\mathrm{M}}=$ quadratic function associated with material effect.

Based on the expected mean squares shown in Table 1, the overall repeatability and reproducibility were estimated according to Mertens (2003):

$$
\begin{aligned}
& r=\hat{\sigma}_{\varepsilon}^{2} \\
& R=\hat{\sigma}_{\varepsilon}^{2}+\hat{\sigma}_{L}^{2}
\end{aligned}
$$

where $\mathrm{r}$ is the repeatability and $\mathrm{R}$ is the reproducibility.

When the interaction effect of material (feed) and laboratory was significant, a new statistical assessment was performed, in which each material was evaluated separately. It is highlighted that, in the presence of interaction, both the repeatability and reproducibility estimated from the variance components obtained from Equation (1) cannot be used to represent the individual pattern of each feed. As random effects are evaluated, it is not possible to perform an outspread of the interaction effect through a single model. It should be noted that random effects are not population parameters. 
Rather, they are continuous random variables. Thus, a common component of variance for laboratory cannot be used for evaluating each feed. Since the outspread in a single model is impossible in this case, the estimation of individual variance components is only possible with the fractioning of the data set. Thus, the outspread was performed using a model for the assessment of the variation of each material considering the different laboratories:

$$
Y_{i j}=\mu+L_{i}+\varepsilon_{(i) j}
$$

where $\mathrm{Y}_{\mathrm{ij}}$ is the NDFi or $\mathrm{iADF}$ content (\%) obtained in the $\mathrm{k}$ replicate in the $\mathrm{i}$ laboratory, $\mu$ is the general constant, $\mathrm{L}_{\mathrm{i}}$ is the effect of $\mathrm{i}$ laboratory (random) and $\mathrm{e}_{(\mathrm{i}) \mathrm{j}}$ is the random error assumed to have normal distribution and homogeneous variance.

The expected mean squares for the model described in (4) are detailed in Table 2. Estimation of repeatability and reproducibility for each material was obtained similarly to that described in Equations (2) and (3).

Table 2. Expected mean squares for the model used in the analysis of each material according to the different laboratories (Equation (4)).

\begin{tabular}{cc}
\hline Variation source $^{1}$ & $\mathrm{E}(\mathrm{MS})^{2}$ \\
\hline $\mathrm{L}$ & $\sigma_{\mathrm{e}}^{2}+\mathrm{k}_{1} \times \sigma^{2}{ }_{\mathrm{L}}$ \\
Residue & $\sigma_{\mathrm{e}}^{2}$ \\
\hline
\end{tabular}

${ }^{1} \mathrm{~L}=$ laboratory; ${ }^{2} \sigma_{\varepsilon}^{2}, \sigma_{\mathrm{L}}^{2}=$ variances associated with the error effects (repeatability) and laboratory, respectively.
For the situation described in Table 2, the expected reproducibility and Horwitz ratio (HORWITZ et al., 1990) were estimated through the equations:

$$
\begin{aligned}
& R s=\frac{\hat{\sigma}_{R}}{\bar{X}} \\
& \hat{\sigma}_{R}=\sqrt{R} \\
& R s e=2 \exp 1-0.5 \log c \\
& H R=\frac{R s}{R s e}
\end{aligned}
$$

where Rs is the standardized reproducibility as a function of the mean, Rse is the expected standardized reproducibility estimated according to the Horwitz method, $\mathrm{c}$ is the average concentration of iNDF or iADF $(\mathrm{g} / \mathrm{g})$ and HR is the Horwitz ratio.

All statistical procedures were performed using SAS (Statistical Analysis System, 9.2), adopting 0.05 as the critical level of probability for type I error. Comparisons between means provided by different laboratories were conducted using the Scheffé's criterion.

\section{Results and Discussion}

All the components of variance of the overall model (Equation (1)) were significant $(\mathrm{P}<0.05)$. This indicates that the estimated contents of iNDF and $\mathrm{AADF}$ were dependent on the laboratory where the analysis was performed. In other words, the different materials produced different estimates according to the laboratory in which the evaluation was conducted (Table 3). 
Table 3. Estimates of the components of variance of the overall model (iNDF and iADF; Equation (1)).

\begin{tabular}{|c|c|c|c|}
\hline Item & Estimates & Relative value (\%) & P-value \\
\hline \multicolumn{4}{|c|}{ iNDF } \\
\hline$\sigma_{\mathrm{L}}^{2}$ & 3.2329 & 50.6 & 0.0002 \\
\hline$\sigma_{\text {LxM }}^{2}$ & 2.7164 & 42.5 & $<0.0001$ \\
\hline Repeatability $\left(\sigma_{\varepsilon}^{2}\right)$ & 0.4455 & 6.9 & \\
\hline Total variance & 6.3948 & 100.0 & \\
\hline Reproducibility & 3.6784 & & \\
\hline $\mathrm{r} / \mathrm{R}^{1}$ & 0.1211 & & \\
\hline Mean & 16.62 & & \\
\hline \multicolumn{4}{|c|}{ iADF } \\
\hline$\sigma_{L}^{2}$ & 1.9731 & 40.7 & 0.0019 \\
\hline$\sigma_{\text {LxM }}^{2}$ & 2.6962 & 55.6 & $<0.0001$ \\
\hline Repeatability $\left(\sigma_{\varepsilon}^{2}\right)$ & 0.1819 & 3.7 & \\
\hline Total variance & 4.8512 & 100 & \\
\hline Reproducibility & 2.1550 & & \\
\hline $\mathrm{r} / \mathrm{R}^{1}$ & 0.0844 & & \\
\hline Mean & 9.92 & & \\
\hline
\end{tabular}

${ }^{1}$ Ratio repeatability/reproducibility.

In general, the occurrence of interaction effect between material and laboratory is unacceptable (MERTENS, 2003). The occurrence of this effect indicates that the bias attributed to such material in one laboratory will be different from that observed in another laboratory. To this is added the fact that the systematic errors imputed to a laboratory will manifest differently depending on the analyzed material. This can cause confusion for the comparison of the chemical characteristics of feeds and other materials such as feces, orts and digesta; which, consequently, may affect the comparison of characteristics obtained in digestion assays or measurements of pasture intake by grazing animals.

The interaction of laboratory and material is supported by the comparative evaluation of the mean values of the different feeds, in which high variability was observed in the behavior of the differences among laboratories, where there was no defined pattern in multiple comparisons. It was found that differences among laboratories ranged from 2.40 percentage points for the soybean meal to 8.05 percentage points for sugarcane for iNDF (Table 4) and 1.79 percentage points for corn to 10.06 percentage points for hay for iADF (Table 4).

The high variability of results among laboratories is reinforced by evaluating the total standardized range between means, which ranged from 22.1 to $158.0 \%$ for $\mathrm{iNDF}$ and 34.9 to $202.6 \%$ for $\mathrm{iADF}$ (Table 4).

Analyzing the individual materials, there was a great variation in reproducibility, that is, in the variation between individual results for the same material, when determined by several laboratories (different analyst, equipment, environment, time, etc.; Figures 1 and 2), which corroborates the interaction effect between laboratory and material (Tables 3 and 4). 
Table 4. Comparison between means of iNDF and iADF contents produced by different laboratories.

\begin{tabular}{ccccccc}
\hline \multirow{2}{*}{ Laboratory } & \multicolumn{7}{c}{ Material $^{1,2}$} \\
\cline { 2 - 6 } 1 & Hay & Sugarcane & CS & Corn & SM & CP \\
\hline & $33.77 \mathrm{ab}$ & $35.58 \mathrm{~b}$ & $22.61 \mathrm{a}$ & $5.50 \mathrm{a}$ & $3.71 \mathrm{a}$ & $5.79 \mathrm{ab}$ \\
3 & $36.92 \mathrm{a}$ & $36.50 \mathrm{ab}$ & $24.89 \mathrm{a}$ & $3.64 \mathrm{~b}$ & $2.43 \mathrm{~b}$ & $5.60 \mathrm{ab}$ \\
4 & $31.35 \mathrm{bc}$ & $30.83 \mathrm{~cd}$ & $17.93 \mathrm{~b}$ & $3.29 \mathrm{~b}$ & $2.87 \mathrm{~b}$ & $5.67 \mathrm{ab}$ \\
5 & $29.55 \mathrm{c}$ & $32.61 \mathrm{c}$ & $18.95 \mathrm{~b}$ & $0.84 \mathrm{c}$ & $2.97 \mathrm{~b}$ & $0.33 \mathrm{c}$ \\
6 & $36.58 \mathrm{a}$ & $38.08 \mathrm{a}$ & $23.96 \mathrm{a}$ & $3.12 \mathrm{~b}$ & $2.46 \mathrm{~b}$ & $6.45 \mathrm{a}$ \\
SEM & $31.77 \mathrm{bc}$ & $30.03 \mathrm{~d}$ & $18.74 \mathrm{~b}$ & $1.29 \mathrm{c}$ & $1.31 \mathrm{c}$ & $5.13 \mathrm{~b}$ \\
TRM $^{3}$ & 2.97 & 3.26 & 3.00 & 1.69 & 0.79 & 1.90 \\
TSRM $^{4}$ & 7.37 & 8.05 & 6.96 & 4.66 & 2.40 & 6.12 \\
& 22.1 & 23.7 & 82.7 & 158.0 & 91.6 & 117.9 \\
1 & & & iADF & & & \\
2 & $14.51 \mathrm{e}$ & $17.17 \mathrm{~d}$ & $9.98 \mathrm{c}$ & $0.98 \mathrm{bc}$ & $0.73 \mathrm{~b}$ & $2.63 \mathrm{c}$ \\
3 & $18.13 \mathrm{~d}$ & $19.73 \mathrm{c}$ & $12.73 \mathrm{ab}$ & $0.54 \mathrm{~cd}$ & $0.32 \mathrm{~b}$ & $2.46 \mathrm{c}$ \\
4 & $24.57 \mathrm{a}$ & $25.10 \mathrm{a}$ & $13.83 \mathrm{a}$ & $1.99 \mathrm{a}$ & $1.81 \mathrm{a}$ & $4.41 \mathrm{a}$ \\
5 & $20.79 \mathrm{~b}$ & $24.90 \mathrm{a}$ & $14.47 \mathrm{a}$ & $0.35 \mathrm{~d}$ & $2.65 \mathrm{a}$ & $0.12 \mathrm{~d}$ \\
6 & $20.64 \mathrm{bc}$ & $23.29 \mathrm{~b}$ & $14.44 \mathrm{a}$ & $1.24 \mathrm{~b}$ & $0.92 \mathrm{~b}$ & $4.35 \mathrm{a}$ \\
SEM & $18.76 \mathrm{~cd}$ & $19.23 \mathrm{c}$ & $11.82 \mathrm{bc}$ & $0.20 \mathrm{~d}$ & $0.47 \mathrm{~b}$ & $3.52 \mathrm{~b}$ \\
TRM $^{3}$ & 3.35 & 3.31 & 1.76 & 0.67 & 0.90 & 1.41 \\
TSRM $^{4}$ & 10.06 & 7.93 & 4.49 & 1.79 & 2.33 & 4.29 \\
\hline
\end{tabular}

${ }^{1} \mathrm{CS}$, corn silage; SM, soybean meal; CP, citrus pulp. ${ }^{2}$ Means in a column followed by different letters are different according to Scheffé's test $(\mathrm{P}<0.05) .{ }^{3} \mathrm{TRM}$, total range between means. ${ }^{4} \mathrm{TSRM}$, total standardized range between means according to the overall mean value $(\%)$.

Figure 1. Reproducibility $\left[(\%)^{2}\right]$ for the materials analyzed for indigestible neutral detergent fiber (iNDF).

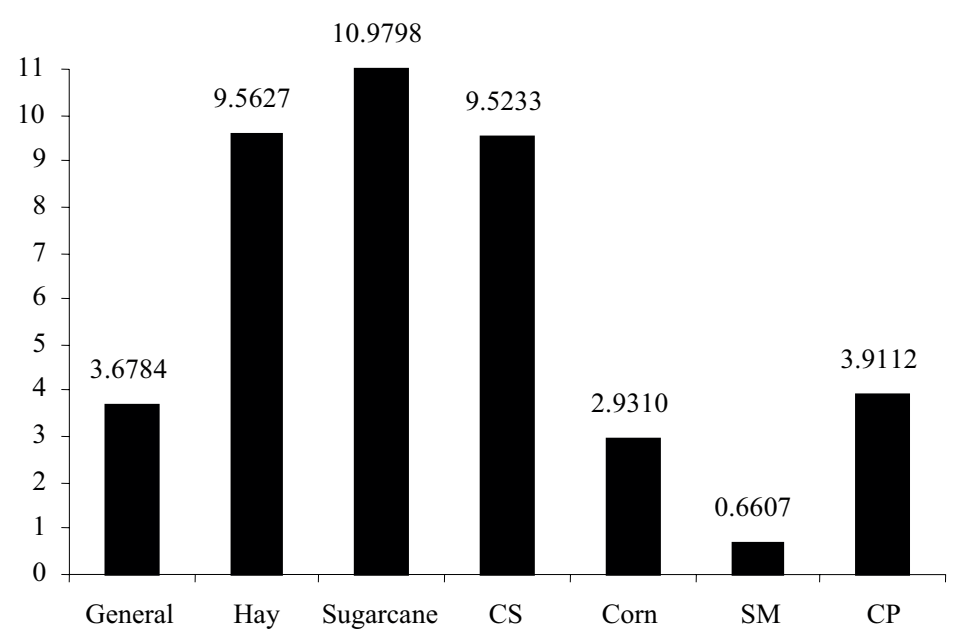

In individual evaluation of each material for the the results between laboratories ranged from 88.75 to iNDF analysis, it was observed that the variation in $96.77 \%$ of the total random variation. Additionally, 
it was found that the repeatability (variation between the results for the same material determined under similar conditions in a laboratory, as typically successive samples within the same period of time: the same analyst, equipment, reagents, etc.) represented 3.23 to $11.25 \%$ of reproducibility (Table 5). For $\mathrm{iADF}$ analysis, it was observed that the variation in the results between laboratories ranged from 88.75 to $98.40 \%$ of the total random variation. As with iNDF, it was found that the repeatability (variation between replicates) represented 1.60 to $11.25 \%$ of the reproducibility for iADF (Table 6). The pattern of these percentages reiterates that differences between laboratories correspond to the determinant factor of the differences between the contents of iNDF and iADF evaluated by in situ procedures.

Figure 2. Reproducibility $\left[(\%)^{2}\right]$ for the materials analyzed for indigestible acid detergent fiber (iADF).

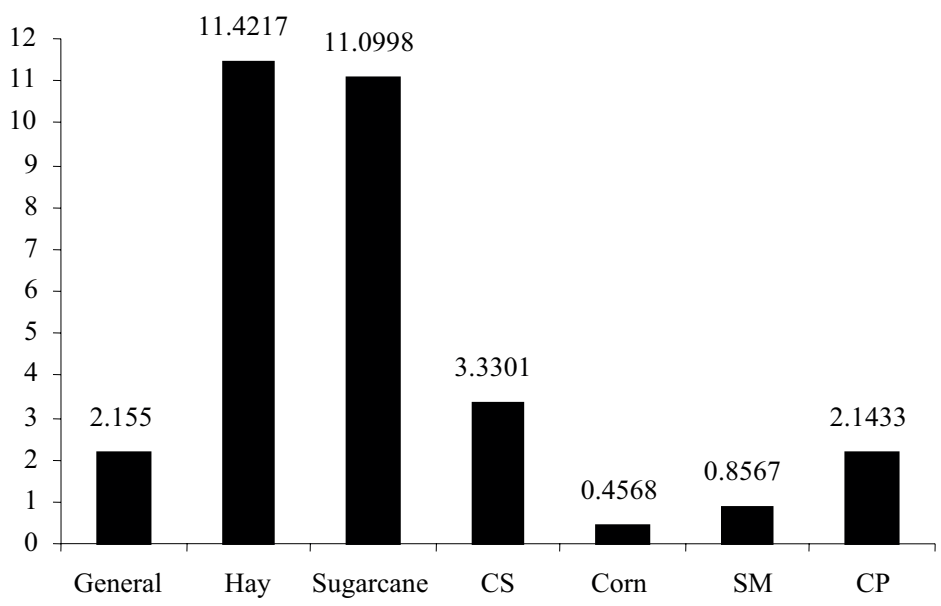

The reproducibility, which represents the sum of repeatability and variation between laboratories, was not acceptable for the evaluated feeds. HR greater than two was observed for all materials evaluated (Table 5). This parameter is the ratio between the observed reproducibility and reproducibility that should be expected considering the average content of the analyzed component (HORWITZ et al., 1990).

With few exceptions, HR higher than two suggests that the method is unacceptable with regard to reproducibility (MERTENS, 2003). Considering this criterion, it could be concluded that the estimation procedures of the internal marker contents present low reproducibility. This may constitute a constraint for comparison of the results of trials of digestion and pasture intake, since these markers are basic tools in most studies conducted on ruminants.

In addition, from the data shown in Table 5, it is estimated that the standardized repeatability (expressed as a percentage of the means) was $3.11 ; 2: 11 ; 4.16 ; 10.99 ; 8.60$ and $6.98 \%$ for hay, sugarcane, corn silage, corn, soybean meal and citrus pulp, respectively, for the iNDF contents. For iADF, standardized repeatability was $3.02 ; 2.23$; $4.75 ; 15.45 ; 23.43$ and $6.01 \%$ for hay, sugarcane, corn silage, corn, soybean meal and citrus pulp, respectively. These estimates indicate a low relative variation between replicates. Therefore, by considering that reproducibility is the sum of variation between replicates and between laboratories, the high HR values (Tables 5 and 6) were caused by the high variation between laboratories. 
High variability was observed in the methods showing possible causes of the high variation of practiced by the different laboratories (Table 6), results (Table 5) and of the interaction between laboratory and material (Table 3 ).

Table 5. Estimates of the components of variance of the model for the individual evaluation of materials (Equation (4)).

\begin{tabular}{|c|c|c|c|c|c|c|}
\hline \multirow[b]{2}{*}{ Item } & \multicolumn{3}{|c|}{ iNDF } & \multicolumn{3}{|c|}{ iADF } \\
\hline & Estimates & $\begin{array}{c}\text { Relative } \\
\text { value }(\%)\end{array}$ & P-value & Estimates & $\begin{array}{c}\text { Relative } \\
\text { value }(\%)\end{array}$ & P-value \\
\hline & \multicolumn{6}{|c|}{ Hay } \\
\hline$\sigma_{L}^{2}$ & 8.4871 & 88.7 & $<0.0001$ & 11.0733 & 97.0 & $<0.0001$ \\
\hline Repeatability $\left(\sigma_{\varepsilon}^{2}\right)$ & 1.0756 & 11.3 & - & 0.3484 & 3.0 & - \\
\hline Total variance & 9.5627 & 100.0 & - & 11.4217 & 100.0 & - \\
\hline Reproducibility & 9.5627 & - & - & 11.4217 & - & - \\
\hline $\mathrm{r} / \mathrm{R}^{1}$ & 0.1125 & - & - & 0.0305 & - & - \\
\hline HR & 3.65 & - & - & 6.06 & - & - \\
\hline \multirow[t]{2}{*}{ Mean } & 33.32 & - & - & 19.57 & - & - \\
\hline & \multicolumn{6}{|c|}{ Sugarcane } \\
\hline$\sigma_{L}^{2}$ & 10.4665 & 95.3 & $<0.0001$ & 10.8694 & 97.9 & $<0.0001$ \\
\hline Repeatability $\left(\sigma_{\varepsilon}^{2}\right)$ & 0.5133 & 4.7 & & 0.2304 & 2.1 & \\
\hline Total variance & 10.9798 & 100.0 & - & 11.0998 & 100.0 & - \\
\hline Reproducibility & 10.9798 & - & - & 11.0998 & - & - \\
\hline $\mathrm{r} / \mathrm{R}^{1}$ & 0.0467 & - & - & 0.0208 & - & - \\
\hline HR & 3.86 & - & - & 5.54 & - & - \\
\hline \multirow[t]{2}{*}{ Mean } & 33.94 & - & - & 21.57 & - & - \\
\hline & \multicolumn{6}{|c|}{ Corn silage } \\
\hline$\sigma_{L}^{2}$ & 8.7483 & 91.9 & $<0.0001$ & 2.9555 & 88.7 & $<0.0001$ \\
\hline Repeatability $\left(\sigma_{\varepsilon}^{2}\right)$ & 0.7750 & 8.1 & - & 0.3746 & 11.3 & - \\
\hline Total variance & 9.5233 & 100.0 & - & 3.3301 & 100.0 & - \\
\hline Reproducibility & 9.5233 & - & - & 3.3301 & - & - \\
\hline$r / R^{1}$ & 0.0814 & - & - & 0.1125 & - & - \\
\hline HR & 5.20 & - & - & 4.54 & - & - \\
\hline \multirow[t]{2}{*}{ Mean } & 21.18 & - & - & 12.88 & - & - \\
\hline & \multicolumn{6}{|c|}{ Corn } \\
\hline$\sigma_{L}^{2}$ & 2.8258 & 96.4 & $<0.0001$ & 0.4379 & 95.9 & $<0.0001$ \\
\hline Repeatability $\left(\sigma_{\varepsilon}^{2}\right)$ & 0.1052 & 3.6 & & 0.0189 & 4.1 & \\
\hline Total variance & 2.9310 & 100.0 & - & 0.4568 & 100.0 & - \\
\hline Reproducibility & 2.9310 & - & - & 0.4568 & - & - \\
\hline $\mathrm{r} / \mathrm{R}^{1}$ & 0.0359 & - & - & 0.0414 & - & - \\
\hline HR & 13.52 & - & - & 13.67 & - & - \\
\hline \multirow[t]{2}{*}{ Mean } & 2.95 & - & - & 0.89 & - & - \\
\hline & \multicolumn{6}{|c|}{ Soybean meal } \\
\hline$\sigma_{L}^{2}$ & 0.6099 & 92.3 & $<0.0001$ & 0.7841 & 91.5 & $<0.0001$ \\
\hline Repeatability $\left(\sigma_{\varepsilon}^{2}\right)$ & 0.0508 & 7.7 & - & 0.0726 & 8.5 & - \\
\hline Total variance & 0.6607 & 100.0 & - & 0.8567 & 100.0 & - \\
\hline Reproducibility & 0.6607 & - & - & 0.8567 & - & - \\
\hline $\mathrm{r} / \mathrm{R}^{1}$ & 0.0769 & - & - & 0.0847 & - & - \\
\hline HR & 7.02 & - & - & 15.26 & - & - \\
\hline Mean & 2.62 & - & - & 1.15 & - & - \\
\hline
\end{tabular}


.. Continuation

\begin{tabular}{ccccccc}
\hline & \multicolumn{6}{c}{ Citrus pulp } \\
$\sigma_{\mathrm{L}}^{2}$ & 3.7849 & 96.8 & $<0.0001$ & 2.1090 & 98.4 & $<0.0001$ \\
Repeatability $\left(\sigma_{\varepsilon}^{2}\right)$ & 0.1263 & 3.2 & - & 0.0343 & 1.6 & - \\
Total variance & 3.9112 & 100.0 & - & 2.1433 & 100.0 & - \\
Reproducibility & 3.9112 & - & - & 2.1433 & - & - \\
$\mathrm{r} / \mathrm{R}^{1}$ & 0.0323 & - & - & 0.0160 & - & - \\
$\mathrm{HR}$ & 10.17 & - & - & 11.16 & - & - \\
Mean & 5.09 & - & - & 3.08 & - & - \\
\hline
\end{tabular}

${ }^{1}$ Ratio repeatability/reproducibility.

Table 6. General characteristics of iNDF and iADF evaluation procedures according to the different laboratories.

\begin{tabular}{|c|c|c|c|c|c|c|c|c|}
\hline \multirow[b]{3}{*}{ Laboratory } & \multicolumn{8}{|c|}{ Pre-incubation and incubation characteristics ${ }^{1}$} \\
\hline & \multirow[b]{2}{*}{ SM } & \multirow[b]{2}{*}{ RSMSB } & \multirow[b]{2}{*}{ NBC } & \multirow[b]{2}{*}{ NBCP } & \multicolumn{2}{|l|}{ DPOT } & \multirow[b]{2}{*}{ IT } & \multirow[b]{2}{*}{$\mathrm{AD}$} \\
\hline & & & & & FVO & NVO & & \\
\hline 1 & 1.0 & 27.8 & $\mathrm{Y}$ & $\mathrm{ND}, \mathrm{HDW}, \mathrm{AC}$ & $60 / 16$ & $105 / 1$ & 288 & $\mathrm{P}+\mathrm{C}$ \\
\hline 2 & 0.8 & 22.2 & $\mathrm{~N}$ & - & - & $105 / 1$ & 144 & $\mathrm{CS}+\mathrm{C}$ \\
\hline 3 & 1.0 & 27.8 & $\mathrm{Y}$ & ND, HDW & $65 / 2$ & - & $\mathrm{NI}^{2}$ & $\mathrm{SC}+\mathrm{C}$ \\
\hline 4 & 0.7 & 19.4 & $\mathrm{Y}$ & $\mathrm{HDW}, \mathrm{AC}$ & $65 / 24$ & $105 / 0,5$ & 264 & $\mathrm{NI}^{2}$ \\
\hline 5 & 0.5 & 13.9 & $\mathrm{~N}$ & - & - & $105 / 1$ & 264 & $\mathrm{P}$ \\
\hline \multirow[t]{3}{*}{6} & 0.45 & 12.5 & $\mathrm{Y}$ & WRT, DWR & - & $105 / 12$ & 240 & $\mathrm{P}+\mathrm{C}$ \\
\hline & \multicolumn{8}{|c|}{ Post-incubation characteristics ${ }^{3}$} \\
\hline & & & & & & \multicolumn{3}{|c|}{ PEDP } \\
\hline Laboratory & CAR & \multicolumn{2}{|r|}{ EDE } & $\mathrm{BDE}$ & CPPE & \multirow{2}{*}{\multicolumn{2}{|c|}{$60 / 16$}} & NVO \\
\hline 1 & RWC & \multicolumn{2}{|r|}{ AFA } & $100 / 1$ & HDW, AC & & & $105 / 1$ \\
\hline 2 & RWC & \multicolumn{2}{|r|}{ AFA } & $105 / 1$ & HDW, AC & \multicolumn{2}{|r|}{$60 / 16$} & $105 / 1$ \\
\hline 3 & $\mathrm{NI}^{2}$ & \multicolumn{2}{|r|}{ AFA } & $100 / 1$ & HDW, AC & \multicolumn{2}{|r|}{-} & $105 / 4$ \\
\hline 4 & RWC & \multicolumn{2}{|r|}{$\mathrm{AC}$} & $120 / 1$ & HDW, AC & \multicolumn{2}{|r|}{$65 / 24$} & $105 / 0,5$ \\
\hline 5 & RWC & \multicolumn{2}{|r|}{ AFA } & $100 / 1,25$ & HWN, HDW, AC & \multicolumn{2}{|r|}{-} & $105 / 16$ \\
\hline 6 & RWC & \multicolumn{2}{|r|}{$\mathrm{AC}$} & $100 / 1$ & $\mathrm{HDW}, \mathrm{AC}$ & & - & $105 / 12$ \\
\hline
\end{tabular}

${ }^{1} \mathrm{SM}$, sample mass (g of as-is sample); RSMSB, ratio of sample mass per surface of the bag (mg/cm²; it was assumed to be 36 $\mathrm{cm}^{2}$ of specific surface area); NBC, new bags cleaning procedure (Y, yes; N, no); NBCP, new bags cleaning procedures described sequentially (ND, neutral detergent boiling; HDW, hot distilled water; AC, acetone; WRT, not distilled water at room temperature; DWR, distilled water at room temperature); DPOT, drying procedures to obtain the tares $\left({ }^{\circ} \mathrm{C} / \mathrm{h}\right.$; $\mathrm{FVO}$, forced ventilation oven; NVO, not ventilated oven); IT, incubation time (h); AD, animal diet (P, pasture; C, concentrated; CS, corn silage; SC, sugarcane). ${ }^{2} \mathrm{NI}$, not identified characteristic. ${ }^{3} \mathrm{CAR}$, cleaning bags after removal from the rumen (RWC, running water until cleaning); EDE, equipment used for detergent extraction (AFA, Ankom analyzer fibers; AC, autoclave); BDE, binomial detergent extraction process $\left({ }^{\circ} \mathrm{C} / \mathrm{h}\right)$; CPPE, cleaning procedures of post extraction bags described sequentially (HDW, hot distilled water; AC, acetone; HWN, hot water not distilled); PEDP, post extraction drying procedure $\left({ }^{\circ} \mathrm{C} / \mathrm{h}, \mathrm{FVO}\right.$, forced ventilated oven; $\mathrm{NVO}$, not ventilated oven).

In any of the evaluated characteristics was found homogeneity between laboratories (Table 6). The mass of incubated samples, in relative terms, ranged from 12.5 to $27.8 \mathrm{mg} / \mathrm{cm}^{2}$ surface of incubation bag. High ratios can compact the sample on the internal microenvironment of the bag and hamper the ruminal fluid flow and the contact thereof with the sample particles, reducing the degradation rate (NOCEK, 1988). Although undegradable fraction is a characteristic of the feed (CASALI et al., 2008), reducing the degradation rate can increase the required time for this fraction 
to be properly estimated (VALENTE et al., 2011b). Furthermore, lower ratios can provide small residues that compromise the quantification of nondegraded material. Additionally, the differences in the mass-surface ratios between laboratories may have contributed to the low reproducibility of results (Table 5).

Two laboratories did not proceed to the preincubation cleaning of the bags (Table 6), which can be a problem if they present impurities, which can distort the tare value. The cleaning and drying procedures of bags to obtain the tares are extremely variable and no pattern could be established. This indicates the urgent need for standardization of methods, because this variation can effectively reduce the reproducibility of the results.

The incubation time is a critical feature for the estimation of undegradable residue (CASALI et al., 2008; VALENTE et al., 2011b). Considering the F57 bags, at least 288 hours are required (VALENTE et al., 2011b). However, only one laboratory used this value. Two laboratories used 264 hours, which is sufficient time for sequential estimation of iNDF and iADF using bags made of non-woven textile (NWT) (CASALI et al., 2008). One of the laboratories used sufficient time (240 hours) to measure iNDF in NWT bags (CASALI et al., 2008). It was found that other laboratories used an extremely short time (144 hours) or the time was unidentifiable (Table 6).

As noted earlier, the undegradable fraction is an intrinsic characteristic of the feed; however, variations in the degradation rate can affect the time required for this fraction to be properly estimated. The ruminal degradation rate can be affected by the diet of the animal, which proved to be highly variable between laboratories and may have contributed to reduction in reproducibility (Table 6).

In all laboratories the extraction with detergent was performed on equipment with pressurized environment, which is recommended in analysis of fibrous compounds using filter bags (GOMES et al.,
2011). However, the binomial suggested for this type of extraction $\left(100^{\circ} \mathrm{C} / 1\right.$ hour) (PELL; SCOFIELD, 1993) was only used in three laboratories (Table 6).

As with the pre-incubation procedures, the cleaning and drying procedures of bags postextraction with detergents were extremely variable, which may have contributed to the low reproducibility and reinforcing once again the need for standardization of methods.

\section{Conclusions}

The content of indigestible neutral detergent fiber and indigestible acid detergent fiber obtained by in situ procedure by laboratories participating in this study are dependent on the interaction effect between material and laboratory. The contents obtained in this study have low reproducibility, a possible consequence of the differences between the methods in each laboratory. The results show a lack of standardization of the procedures adopted in the laboratories.

\section{Acknowledgments}

To INCT-Animal Science, CNPq and FAPEMIG for the financial support.

\section{References}

BARBIN, D. Componentes de variância: teoria e aplicações. 2. ed. Piracicaba: FEALQ, 1993. 120 p.

CASALI, A. O.; DETMANN, E.; VALADARES FILHO, S. C.; PEREIRA, J. C.; HENRIQUES, L. T.; FREITAS, S. G.; PAULINO, M. F. Influência do tempo de incubação e do tamanho de partículas sobre os teores de compostos indigestíveis em alimentos e fezes bovinas obtidos por procedimentos in situ. Revista Brasileira de Zootecnia, Viçosa, v. 37, n. 2, p. 335-342, 2008.

DETMANN, E.; SOUZA, A. L.; GARCIA, R.; VALADARES FILHO, S. C.; CABRAL, L. S.; ZERVOUDAKIS, J. T. Avaliação do vício de tempo longo de indicadores internos em ensaio de digestão com ruminantes. Arquivo Brasileiro de Medicina Veterinária e Zootecnia, Belo Horizonte, v. 59, n. 1, p. 182-188, 2007. 
DETMANN, E.; VALADARES FILHO, S. C.; PAULINO, M. F. Predição do valor energético de dietas para bovinos a partir da composição química dos alimentos. In: VALADARES FILHO, S. C.; MARCONDES, M. I.; CHIZZOTTI, M. L.; PAULINO, P. V. R. (Ed.). Exigências nutricionais de zebuinos puros e cruzados BR-CORTE. Viçosa, MG: DZO-UFV, 2010. p. 47-64.

DETMANN, E.; VALADARES FILHO, S. C.; PAULINO, M. F.; ZERVOUDAKIS, J. T.; CABRAL, L. S. Avaliação da técnica dos indicadores na estimação do consumo por ruminantes em pastejo. Cadernos Técnicos de Veterinária e Zootecnia, Belo Horizonte, n. 46, p. 4057, 2004.

GOMES, D. I.; DETMANN, E.; VALENTE, T. N. P.; VALADARES FILHO, S. C.; QUEIROZ, A. C. Avaliação laboratorial de compostos fibrosos em alimentos e fezes bovinas sob diferentes ambientes físicos. Arquivo Brasileiro de Medicina Veterinária e Zootecnia, Belo Horizonte, v. 63, n. 2, p. 522-525, 2011.

HORWITZ, W. A.; ALBERT, R.; DEUTSCH, M. J.; THOMPSON, J. N. Precision parameters of methods of analysis required for nutrition labeling. Part I. Major nutrients. Journal of AOAC International, Rockville, v. 73, n. 5, p. 661-680, 1990.
MERTENS, D. R. Challenges in measuring insoluble dietary fiber. Journal of Animal Science, Champaign, v. 81, n. 12, p. 3233-3249, 2003.

NOCEK, J. E. In situ and other methods to estimate ruminal protein and energy digestibility: A Review. Journal of Dairy Science, Champaign, v. 71, n. 8, p. 2051-2069, 1988.

PELL, A. N.; SCHOFIELD, P. Computerized monitoring of gas production to measure forage digestion in vitro. Journal of Dairy Science, Champaign, v. 76, n. 4, p. 1063-1073, 1993.

VALENTE, T. N. P.; DETMANN, E.; VALADARES FILHO, S. C.; CUNHA, M.; QUEIROZ, A. C.; SAMPAIO, C. B. In situ estimation of indigestible compounds contents in cattle feed and feces using bags made from different textiles. Revista Brasileira de Zootecnia, Viçosa, v. 40, n. 3, p. 666-675, 2011 a.

VALENTE, T. N. P.; DETMANN, E.; QUEIROZ, A. C.; VALADARES FILHO, S. C.; GOMES, D. I.; FIGUERAS, J. F. Evaluation of ruminal degradation profiles of forages using bags made from different textiles. Revista Brasileira de Zootecnia, Viçosa, v. 40, n. 11, p. 2565-2573, 2011b. 
